Portland State University

PDXScholar

12-6-1985

\title{
The Effects of Maternal Support and Non-support on the Family Concepts of Sexually Abused Girls
}

Sharon R. Hitchens

Portland State University

Follow this and additional works at: https://pdxscholar.library.pdx.edu/open_access_etds

Part of the Counseling Psychology Commons, and the Sociology Commons Let us know how access to this document benefits you.

\section{Recommended Citation}

Hitchens, Sharon R., "The Effects of Maternal Support and Non-support on the Family Concepts of Sexually Abused Girls" (1985). Dissertations and Theses. Paper 3441.

https://doi.org/10.15760/etd.5325

This Thesis is brought to you for free and open access. It has been accepted for inclusion in Dissertations and Theses by an authorized administrator of PDXScholar. Please contact us if we can make this document more accessible: pdxscholar@pdx.edu. 
AN ABSTRACT OF THE THESIS OF SHARON R. HITCHENS for the Master of Science in Psychology presented December 6, 1985.

Title: The Effects of Maternal Support and Non-support on the Family Concepts of Sexually Abused Girls

APPROVED BY MEMBERS OF THE THESIS COMMITTEE:

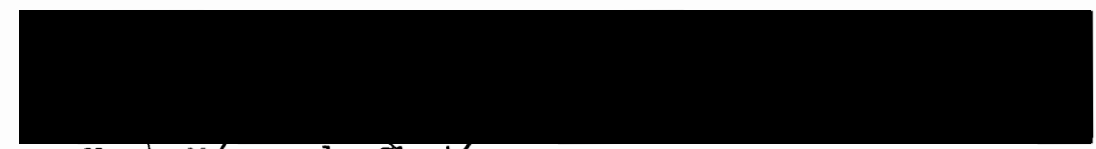
Huga Maynard, Chair

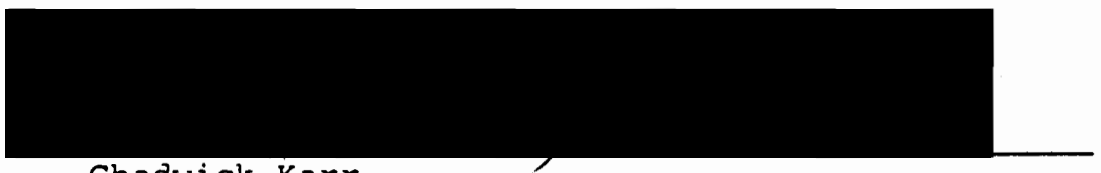

Chadwick Karr

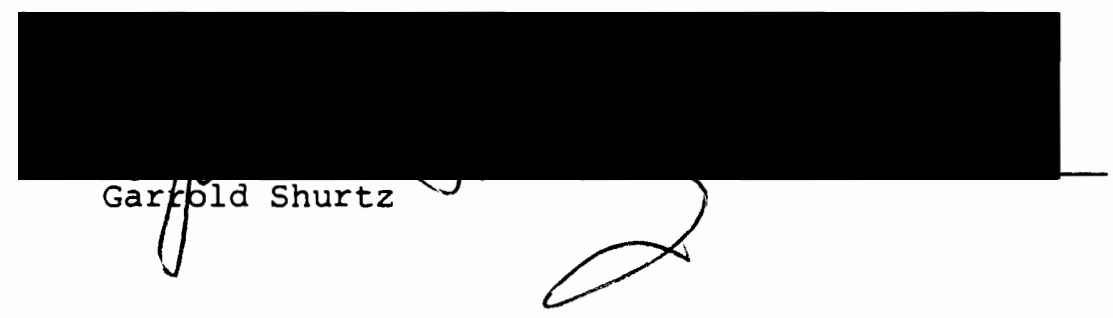

Incest, and the problems arising from it, have increasingly come under the scrutiny of therapists and researchers. All family members are affectea by incest and all have been studied. Victims are particularly devastated by sexual abuse by a family member but it is a commonly held belief that having a supportive mother can mitigate the trauma a victim experiences. In this study, girls between the ages of ten and eighteen who were the victims of sexual abuse by a father-figure were compared to a group of girls not thought to be incest victims. The incest victims were divided into two groups, 
those with supportive mothers and those with non-supportive mothers, with support being defined as belief that sexual abuse occurred and action taken to have the offender leave the home. The Family Concept Inventory was the basis of comparison. Family Effectiveness, the degree to which a test taker's ratings of his or her real and ideal families match professional therapists' ratings of the ideal family, and Family Satisfaction, the comparison of the Real and Ideal Family Effectiveness scores, are obtained from the Inventory. There was no statistically significant difference across the three groups on any of the three measures. However, incest victims with nonsupportive mothers had significantly lower Real Family Effectiveness scores than did incest victims with supportive mothers and the control group. On Family Satisfaction the scores of incest victims with non-supportive mothers were lower than the scores of incest victims with supportive mothers, but this difference was not statistically significant. Incest victims with non-supportive mothers clearly view their families as less effective than do incest victims with non-supportive mothers and non-incest victims. However, they remain attached to their families and in need of them and cannot bear the thought of losing their families. This may explain, in part, the reason there was not a statistically significant difference in Family Satisfaction between the two groups of incest victims. 
THE EFFECTS OF MATERNAL SUPPORT AND NON-SUPPORT ON THE FAMILY CONCEPTS OF SEXUALIY ABUSED GIRLS

\title{
by
}

SHARON R. HITCHENS

\begin{abstract}
A thesis submitted in partial fulfillment of the requirements for the degree of
\end{abstract}

\author{
MASTER OF SCIENCE \\ in \\ PSYCHOLOGY
}

Portland State University

(C) 1985 Sharon R. Hitchens 
TO THE OFFICE OF GRADUATE STUDIES AND RESEARCH

The members of the Committee approve the thesis of Sharon $R$. Hitchens presented December 6, 1985 .

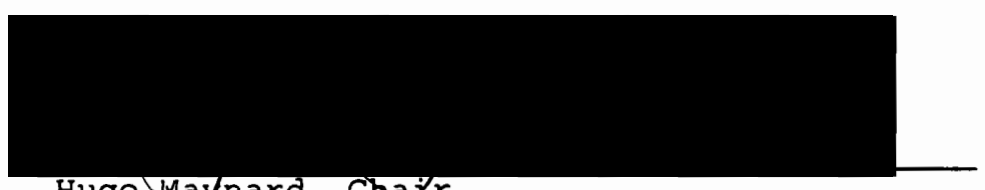

Hugo Maynard, Chä̌r

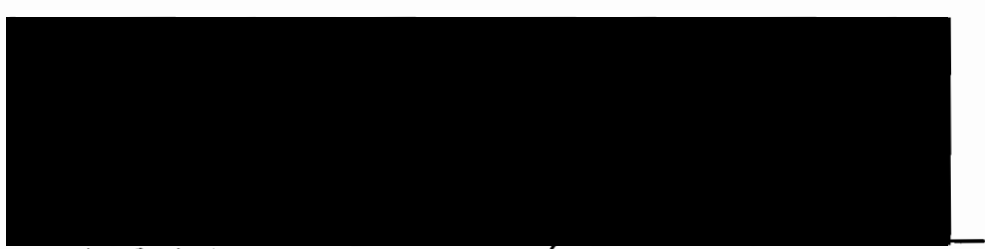

Chadwick Karr
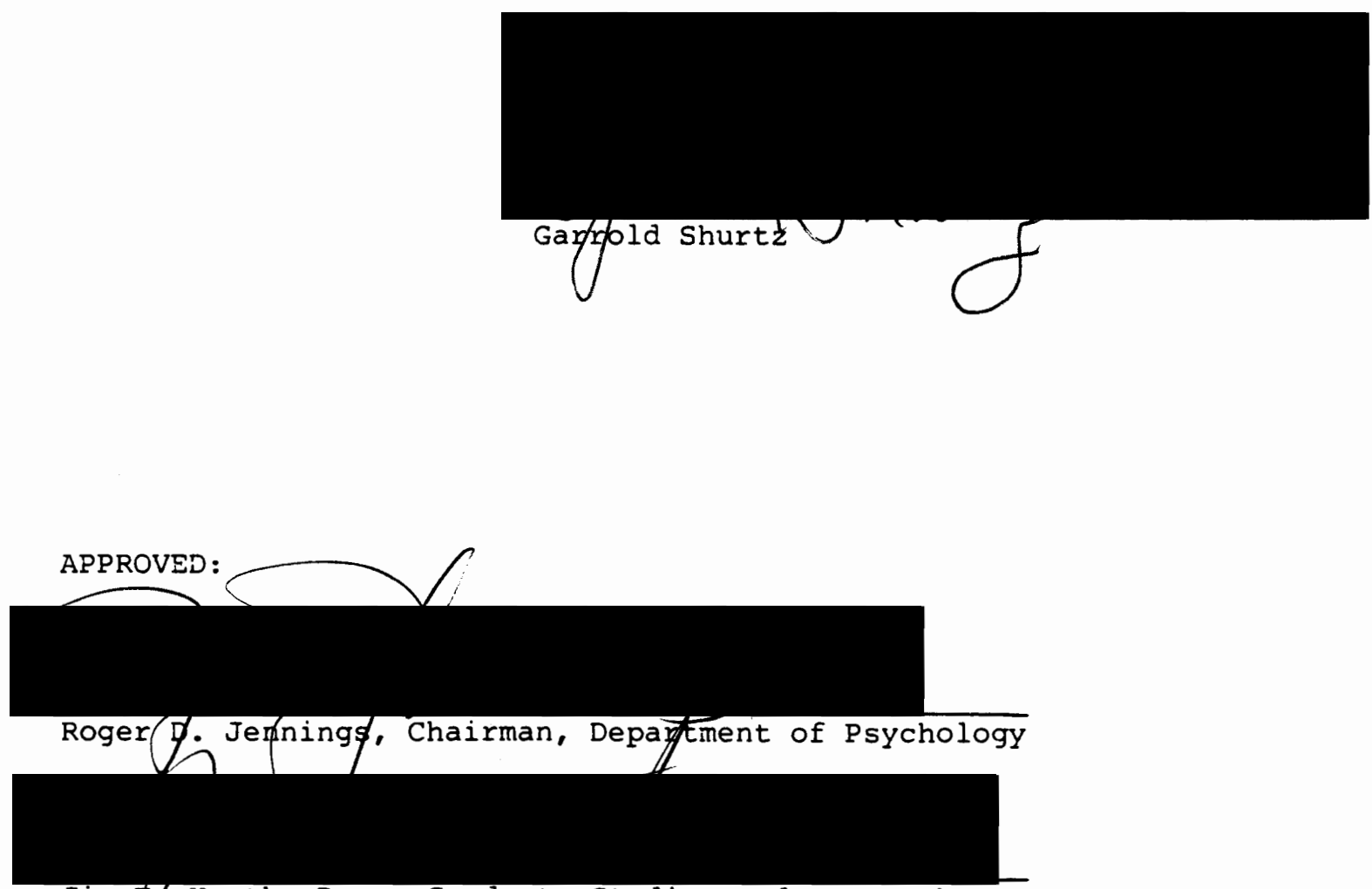

Jim Heath, Dean, Graduate Studies and Research 


\section{ACKNOWLEDGEMENTS}

I am indebted to the service workers, supervisors, and branch manager of the Washington Branch of Children's Services Division for their help in data collection and their support, encouragement, and interest. My thesis committee members were helpful above and beyond the call of duty and to them I will be forever grateful. I am also especially thankful to Russ Dent, who helped me immeasureably with the computer work, and to my husband, who has put up with my insanity through this experience. My real debt, however, is to the children who struggle with the problem on which this study is based. Thank you. 
TABLE OF CONTENTS

PAGE

ACKNOWLEDGEMENTS iii

LIST OF TABLES

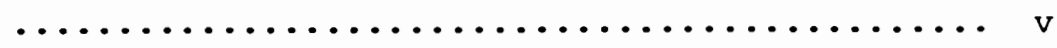

CHAPTER

I INTRODUCTION $\ldots \ldots \ldots \ldots \ldots \ldots \ldots \ldots \ldots \ldots \ldots \ldots \ldots \ldots \ldots \ldots \ldots$

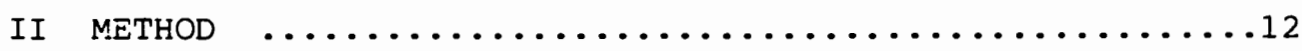

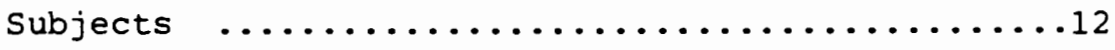

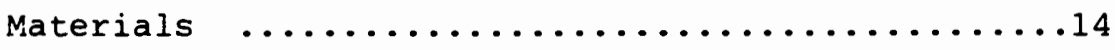

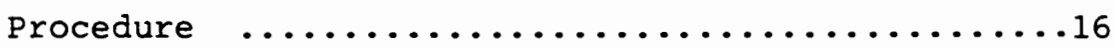

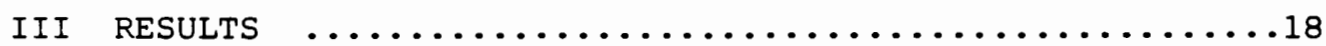

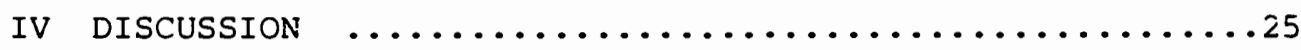

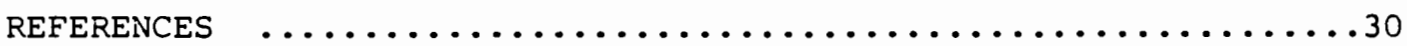

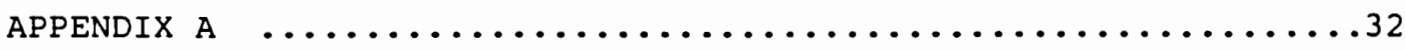

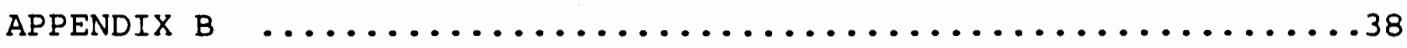

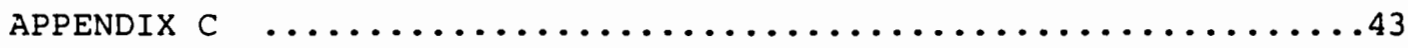




\section{LIST OF TABLES}

TABLE

PAGE

I Mean Ages and Standard Deviations

of Children in the Three Experimental Groups .......18

II Position in Family of Children

in the Three Experimental Groups ................ 19

II Composition of Families of Children

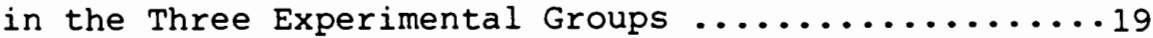

IV Yearly Family Income Approximated From

Miedian Income Levels for Census Tracts

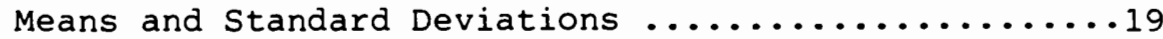

V Physical and Emotional Abuse

of Children in the Three Experimental Groups .....20

VI Type of Sexual Abuse of Incest Victims ..............20

VII Year Sexual Abuse Uncovered .....................2I

VII Real Family Effectiveness Scores

Means and Standard Deviations ...............21

IX Ideal Family Effectiveness Scores

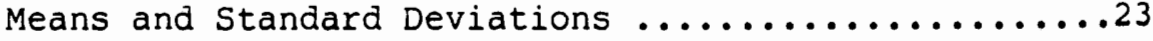

X Family Satisfaction Scores

Means and Standard Deviations $\ldots \ldots \ldots \ldots \ldots \ldots \ldots$

XI Ages of Subjects $\ldots \ldots \ldots \ldots \ldots \ldots \ldots \ldots \ldots \ldots \ldots \ldots \ldots \ldots \ldots$ 


\section{LIST OF TABLES CONTINUED}

Table

XII Median Income Levels for Census Tracts

$$
\text { of Subjects' Residences } \ldots \ldots \ldots \ldots \ldots \ldots \ldots \ldots \ldots \ldots
$$

XIII Real Family Effectiveness Scores $\ldots \ldots \ldots \ldots \ldots \ldots \ldots \ldots \ldots$

XIV Ideal Family Effectiveness Scores $\ldots \ldots \ldots \ldots \ldots \ldots \ldots \ldots \ldots$

XV Family Satisfaction Scores $\ldots \ldots \ldots \ldots \ldots \ldots \ldots \ldots \ldots \ldots$ 


\section{Chapter I}

\section{Introduction}

The serious problems arising from the sexual abuse of children have increasingly come under the scrutiny of professional therapists and researchers as well as the general public in the past few years. The interest in these problems appears justified since approximately $38 \%$ of all female children experience sexual abuse and $16 \%$ are victims of incest (Russell, 1984). Sexual abuse and its after effects can be devastating to the victim and her family, and there is great concern regarding how best to assist the individuals involved. The following accounts of the characteristics of individuals and family relationships and interactions within incest families have come from researchers and therapists studying and working with the families. They have attempted to evaluate the families from their vantage point outside the family systems.

Incest as one of the forms of sexual abuse of children, is a particularly insidious problem as it is perpetrated by a family member who often uses his relationship with the victim to gain her trust and then intimidates her into secrecy through use of his age, size, position in the family, threats of punishment, not being believed, breaking up the family, etc. (In this paper, the only form of incest that is considered is overt sexual behavior between a 
child and an adult who relates to that child as a parental figure.) Incest victims usually believe what is being told them because older people, especially adults in their family, are to be respected. The victims come to believe, once they realize that the incestuous behavior is not right, that they are at fault because the offender cannot be wrong or guilty. Usually they can turn to no one in the family for assistance, not even their mothers, because they believe what the abuser has told them about their mothers and others not believing them. Often this is indeed the case-mothers in incest families may not believe their daughters, or if they do believe that the sexual abuse has occurred, they do not take the action necessary to insure that their daughters feel protected and supported.

In an effort to understand and aid incest victims and their families, numerous theorists have studied families and attempted to explain how and why the sexual abuse occurs. Families in which incest occurs have been seen as dysfunctional units in which all energies go toward keeping the family unit together and there is little or no involvement in the surrounding culture (Lustig, Dresser, Spellman, \& Murray, 1966). The parents have a poor relationship with each other, and the incest reduces the tension in this relationship and keeps the family together (Gentry, 1978). The family as a whole has been compared to a character disordered individual (Anderson \& Shafer, 1979). There are difficulties with impulse control, poor judgment, conflicts with authority, lack of verbal expression of feelings, irresponsibility, lack of guilt, narcissism and self-indulgence, low anxiety, conflicts 
over dependency, and an inability to tolerate intimacy. In addition, manipulation is used to gain satisfaction of needs. One or more of these traits are seen in each family member in an incest family (Anderson \& Shafer, 1979).

As mentioned above, families in which incest occurs tend to be isolated from the rest of society. There are strong boundaries between the family and the outside world (Taylor, 1984). However, within the family there are weak boundaries between family members and the family unit can be viewed as an enmeshed system. Roles within the family are confused and reversed, especially between mothers and daughters (Borgman, 1984; Herman \& Hirschman, 1981; Spencer, 1978; Vander Mey \& Neff, 1982). There is also an intense fear of abandonment felt by family members (Taylor, 1984). The family is the only source of relationships with people that is available, and it must remain intact. Family members will do anything, even endure sexual abuse or deny its existence, to keep the family together. There are casualties in this endeavor, but an individual is expendable, the family is not. Individual family members in incest families have also been studied and their behavior has been explained in various ways. Incest offenders are usually described as rigid, authoritarian, dominant, controlling, and somewhat paranoid (Cavallin, 1966; de Young, 1982; Gordon \& O'Keefe, 1984; Herman \& Hirschman, 1981; Spender, 1978; Taubman, 1984; Vander Mey \& Neff, 1982). Taubman (1984) also describes them as dependent and generally irresponsible individuals. Incest offenders have often experienced emotional deprivation and desertion 
in their youth, especially by their mothers (Cavillin, 1966; Lustig et al., 1966). These men are immature (Berry, 1975; Taubman, 1984) and have fragile egos which are capable of regression. If regression occurs, sexual acting out may occur (Gentry, 1978; Lustig et al., 1966).

Incest offenders are insecure about their masculinity (spencer, 1978) and their power in the community. Therefore, they need to exercise a great deal of control within their families. They are threatened by the involvements of family members in activities and relationships outside the home and intimidate their wives and children into doing as they, the men, want (Herman \& Hirschman, 1981; Vander Mey \& Neff, 1982). Wives and children usually stay at home unless at school or work, have few, if any, friends, do all household chores and duties, and can never question this arrangement.

Men who sexually abuse their children often have difficulties in their relationships with their wives because of problems with intimacy and communication in both parties. These men usually feel sexually abandoned by their wives, which triggers their desertion anxiety, and they look for someone to fill the void in their lives. Their children are chosen because these men know their power over the children. They know the children will trust their judgment and actions and will keep the sexual abuse a secret if this is demanded of them. Incest offenders court their daughters, developing a special relationship with them (Spencer, 1978). The children are conditioned to accept their father's advances and may question the behavior but will comply since he is trusted. 
In attempting to understand incest offenders, there is another problem area that must be considered, perhaps before anything else. In order for a man to abuse children sexually, he must have developed an inappropriate sexual arousal pattern. Normally, adult men are not sexually attracted to children, or if sexually aroused by children they do not act on the arousal. Incest offenders may have adequate sexual relationships with their wives, but because they are attracted to children, sexual relations with their chilaren are more gratifying and therefore can become quite compulsive.

Mothers in incest families are described as dependent, masochistic, having low self-esteem, angry, afraid of intimacy, lacking in social skills, not psychologically invested in their children, and prone to use denial as a defense mechanism (Berry, 1975; Lustig et al., 1966; Spender, 1978; Taylor, 1984; Zuegler \& Reposa, 1983). Taubman (1984) found these women to be weak and submissive, frigid or promiscuous, and indifferent to the needs of others. Often the mothers are ill, disabled, or incapacitated (de Young, 1982; Herman \& Hirschman, 1981) or absent, at least for a period of time, (Herman \& Hirschman, 1981; Vander Mey \& Neff, 1982). These women were often sexually abused as children themselves (Berry, 1975; Spencer, 1978).

Mothers in incest families typically had difficult childhoods during which their emotional needs were not met. They become dependent on the family they create through marriage and children for contact and the gratification of emotional needs (zuelger \& Reposa, 1983). These women will go to any length to obtain the 
mothering and protection they missed as children and to keep their families together. Due to having been physically or psychologically deserted as children (Barry, 1975; Lustig et al., 1966) they have strong anxiety anc fear of family disintegration (de Young, 1982; Zuelger \& Reposa, 1983) and a fear of abandonment (Taylor, 1984). There is a strong need to prevent abandonment and this is based on a preoccupation with the mothers' own needs. These women present themselves as deeply concerned parents who have sacrificed their own happiness to keep their families together (Spencer, 1978). In reality their desire to keep their families together is based on the mothers' own needs and is not an effort to do what is best for the children.

Undoubtedly the most notable characteristic of mothers in incest families is their tendency to abdicate their roles as mothers in their families. Due to their low self-esteem, these women feel inadequate to carry out their roles in the family (Spencer, 1978). The daughters in these families end up taking on the mother role and the mothers can then obtain the mothering they so desperately need (Barry, 1975; Borgman, 1984; de Young, 1982; Herman \& Hirschman, 1981; Lustig et al., 1966; Spencer, 1978; Taubman, 1984; Taylor, 1984; Vander Mey \& Neff, 1982).

Despite the fact that the sexual abuse is occurring in their homes, mothers in incest families are either oblivious to it or deny it (Vander Mey \& Neff, 1982; Zuelger \& Reposa, 1983). Sometimes these women are even collusive with their husbands in the abuse. Once the abuse comes to light, these mothers often disbelieve or 
blame their daughters (Lustig et al., 1966; Spencer, 1978). They cannot admit that this abuse is occurring since it would probably mean the breakup of their families. Their fears of separation and abandonment make it impossible for these women to face the possibility of family dissolution.

Incest victims basically accept anything in their families in order to preserve the family units (Zuelger \& Reposa, 1983). They have received little nurturing from their mothers and fear that there will be nothing for them if their families break up. They accept the role reversal with their mothers to reduce tension in their families and to keep their families together. Stress and pressure decrease for the mother and father in an incest family when mother-daughter roles reverse. Mothers no longer feel the need to carry out activities they feel they cannot do adequately, and fathers have their needs met by their daughters. However, stress and responsibility increase for the daughters who are ill equipped to deal with this situation (Taylor, 1984).

The secrecy forced on them by the sexual offenders is another overwhelming source of stress for the victims of incest. They feel they can tell no one, and if they did tell, no one would believe them. In many cases, victims attempt to tell someone, their mothers or other family members, and are not believed. After this they give up trying to make anyone understand what is going on and engage in acting out and often self damaging behavior. Many girls run away or become depressed and suicidal (Molnar \& Cameron, 1975). They are 
often confused about their sexuality and may become sexually promiscuous (Rist, 1979) or act out sexually against another child. Many victims confuse sex and affection because their fathers made affectionate behavior sexual and they became the objects of sexual desire when they were very young and had no concept of this being different from affection. Incest is usually devastating to children, but like their mothers, their families are more important than anything to them, and they will risk anything to keep the family together. These children are starved for attention and affection and the sexual abuse at least offers some attention and felt affection (de Young, 1982). They are conditioned to accept the sexual advances of their fathers because they have basically been courted by these men (Spencer, 1978). The fathers are also in positions of authority in their families and victims are not in a position to assert themselves against their fathers.

As difficult as the sexual abuse itself is to live with and try to recover from, perhaps even more devastating to children who are victims of incest is their mothers' disbelief that incest is occurring. In a study of twenty-eight victims of sexual abuse, Adams-Tucker (1982) found that all victims had some emotional disturbance. The most severely disturbed children were females who were not supported by their mothers. In cases of incest where a child is not believed and supported by her mother, the child must be removed from the home to protect her from the offender. It is clear that this would cause overwhelming anxiety, fear, and feelings of failure 
and hopelessness since what the child fought so hard to prevent by suffering the abuse, the loss of her family, happens despite her victimization and because of it.

The accounts of the characteristics of indivicuals and family relationships and interactions within incest families that have come from researchers and therapists studying and working with the families have been quite interesting and useful and have provided a basis for interpreting what occurs in incest families. Perhaps, though, it would be more enlightening and beneficial to uncover how the family members view themselves and their families. Since there is much interest in determining how to help individual family members deal with the sexual abuse and their feelings about it as well as their feelings about themselves, each other, and the family as a whole, it seems imperative to determine first just how family members do feel about each other and their families.

Incest victims often seem to feel a special burden to deny or repress certain feelings about the sexual abuse, the offender, and their mothers in order for their families to reintegrate once the sexual abuse has come to light. They appear to want this reintegration but they are confused by their conflicting emotions about their family and the people in it. In order to help incest victims deal with this dilemma, their feelings-especially those that are contradictory or ambivalent-must be brought out into the open. Incest victims whose mothers do not believe that the sexual abuse occurred or who fail to offer the victims any emotional support 
after the abuse comes to light, appear to be even more traumatized than victims who are believed and supported by their mothers. If maternal support actually does make a difference in how incest victims feel about themselves, the sexual abuse, and their families, then these diffrences shoula be uncovered so that incest victims can be better assisted in resolving their feelings about their families, and so mothers and offenders can gain more understanding of how to be supportive of victims. My study looked at the effects mothers' support had on the family concepts of girls who have been sexually abused.

In order to gain some understanding of what effect maternal support has on incest victims, I assessed feelings that victims have about their families. I compared the feelings of victims who have maternal support to the feelings of victims who are not supported by their mothers. Overall, incest victims' feelings about their families were compared with feelings held by a group of female children not known to be sexually abused.

Because of the high base rate of sexual abuse in the general population (Russell, 1984), it is possible that there were some incest victims within this "normal" sample whose abuse has not been uncovered. These control group children have been questioned by their social service workers about the occurrence of sexual abuse, but incest victims often do not divulge this information, even under direct questioning, due to the pressure put on them by the offender, their 
fear that their families will be torn apart, embarrassment, and many other reasons. On the other hand, due to professional involvement with these children and knowledge of their situations, it was less likely that there were unknown incest victims within this group than in the population at large. 
Chapter II

Method

\section{Subjects}

Subjects for the study were $40 \mathrm{girls}$ whose families have open, or recently closed, cases with the Washington County branch office of the State of Oregon's Children's Services Division. The experimental group subjects were girls who have identified themselves as victims of sexual abuse by a father figure. A father figure was defined as a father, step-father, or mother's boyfriend who lived in the household. When a sex abuse victim comes to the attention of Children's Services Division, a Child Protective Service worker meets with the child's mother to inform the mother of what allegations the child has made. The mother then has the opportunity to tell the worker how she feels about her child's statements and whether she believes them or not. Sex abuse victims are usually placed in a shelter home for at least one night to allow their mothers time to decide how they will handle their home situations. If a mother believes her daughter and, with the assistance of a law enforcement official, asks her mate, the offender, to leave the home, the victim is allowed to return to her mother's home. If a mother does not believe her daughter's allegations and continues to live with the offender, the daughter remains in substitute care. The actions of believing 
her daughter and having the offender leave the home are what define a mother as supportive. If these things do not happen, a mother is defined as non-supportive. One experimental group consisted of 13 girls with supportive mothers and the other experimental group consisted of $14 \mathrm{girls}$ with non-supportive mothers.

The control group consisted of 13 girls who have not identified themselves as victims of any sexual abuse. Their parents, or the court, have requested assistance from Children's Services Division because the children are causing family problems, having problems in school or in the community, or are beyond the control of their parents. Within this group, six girls reside in their family homes and seven girls are in substitute care, either foster care or a group living situation.

Children's Services Division had knowledge of the proposal and gave its permission for girls for whom it has been appointed guardian to participate in the study. The mothers of victims who remain in their family home and parents' custody were approached regarding the proposed study and whether or not they would grant permission for their daughters to participate. The parents of subjects for the control group who retain custody of their daughters were also asked to grant permission for their daughters to participate.

The subjects in the experimental and control groups were compared on age, position in family, composition of family, area of residence (i.e. rural or urban), approximate socioeconomic 
status, and whether or not they have suffered physical and/or emotional abuse by their parents. The socioeconomic status of each subject was approximated by using the median yearly income for residents of the various census tracts in which the subjects' families lived. The subjects in the two experimental groups, incest victims with supportive mothers and victims with non-supportive mothers, were compared additionally on the type of sexual abuse that occurred and the length of time since the sexual abuse was uncovered. The definition of the abuse event was taken from the child's allegation.

Materials

To determine how subjects feel about their fmailies, each child completed the Family Concept Inventory devised by Ferdinand van der Veen (van der Veen \& Olson, 1983). This paper-and-pencil test consists of 80 items that describe the social and/or emotional aspects of family life. Examples of the items found on the Inventory are "We like to do new and different things.", "We often upset each other without meaning to.", and "We have very good times together.". (For a complete listing of the items, refer to the Family Concept Inventory in Appendix C.) There are two parts to the Inventory. In the first part, a test taker is instructed to rate each item for her real family, or family as it is now. In the second part the test taker rates the same items for her ideal family. Each item is rated on a scale of 0 to 8 , with 0 being "least like" 
and 8 being "most like" the family as it is at the present time or least or most like the ideal family. To insure that subjects could read and understand the Inventory, only girls aged ten through eighteen were asked to participate in the study.

Measures of Family Effectiveness and Family Satisfaction have been developed from the Family Concept Inventory. Family Effectiveness is the extent to which a test taker's family concept contains qualities that professional clinicians consider important for good family life. Forty-eight of the 80 items have been found to have high consensus among 27 professional clinicians in their description of the ideal family and are used to determine this measure. If a test taker rates one of the 48 items on the same side of neutral as the clinicians' ideal, it is counted toward that test taker's Family Effectiveness score. Family Satisfaction is a measure of the difference between the rating of the family as it is now and the rating of the ideal family. The Family Satisfaction score is the correlation between a test taker's real and ideal family concept item scores.

The Family Concept Inventory has been found to be fairly reliable (van der Veen \& Olson, 1983). The mean $\underline{r}$ for Real Family Effectiveness was .94, for Ideal Family Effectiveness was .78 and for Family Satisfaction was .90 , in a study of fifteen subjects in which the test-retest time span was four weeks. The Inventory has also proved to have good validity: children's Family Effectiveness and Family Satisfaction scores are positively 
related to their scores on the California Psychological Inventory $\underline{\underline{r}}=.74$ for Real Family Effectiveness, $\underline{r}=.50$ for Ideal Family Effectiveness, and $\underline{r}=.71$ for Family Satisfaction), parent's Family Effectiveness and Family Satisfaction scores are positively related to their scores on the Locke Marital Adjustment Questionnaire short form $\underline{\underline{r}}=.67$ for Family Effectiveness and $\underline{r}=.60$ for Family Satisfaction), and the scores on the Inventory are related to behavioral characteristics of family interaction as seen in therapy (van der Veen \& Olson, 1983).

$\underline{\text { Procedure }}$

I consulted with social service workers at Children's Services Division regarding possible subjects for the study and whether or not it would be in the children's best interests to be tested. I then obtained demographic information on possible subjects for the two experimental groups and the control group from the girls' social service workers. These children were then interviewed and told about the purpose of the study (to help children and their families), the Family Concept Inventory, and the testing procedure. Their parents or guardians were given the same information by interview or by letter. All parties were assured of anonymity. Permission forms were given to the parents or guardians of the children. Only those children were tested whose parents or guardians gave their consent in writing for the children to participate in the study. All documents used in this approach phase of the study appear in Appendix B. 
Many incest victims attend support groups for incest victims at Children's Services Division. I administered the Inventory to six girls when they came in for a weekly group session. Five of these girls were in the group with supportive mothers and one was in the group with non-supportive mothers. If a girl was absent from the group session on the day the test was administered, or did not attend group, or was a subject in the control group, the test was administered on an individual basis either at the Children's Services Division office or in the child's home, be it family home or foster home. Five subjects, one in the experimental group with non-supportive mothers and four in the control group, were tested by their social service workers who administered the tests in the same manner as did I. Before being tested, each subject was asked to read a consent form explaining the research study and her participation. It was made clear to each girl that her participation was completely voluntary and that she could decline if she wished.

Test forms for subjects in the experimental groups were numbered, as were cards containing demographic information on each subject that accompanied the test forms. No identifying information accompanied the test forms so that no particular subject's answers could be identified by name.

Following the testing procedure, each subject was given an opportunity to discuss her feelings about the test and the testing procedure. The subjects were also given my business card and encouraged to call me if they had any questions or problems afterwards. 
Chapter III

Results

A summary of the demographic information on the three groups studied-incest victims with supportive mothers, incest victims with non-supportive mothers, and the control group of non-incest victims-is presented in Tables I through $V$. The individual data for each subject are found in Appendix A. The groups were well matched for age, position in family, family composition, and the occurrence of physical and emotional abuse. As shown in Table IV, families of incest victims with supportive mothers had higher incomes than either of the other two groups with the difference between this group and the non-supportive group being statistically significant, $\underline{t}(24)=2.59$, $\underline{p}<.01$.

\section{Table I}

Mean Ages and Standard Deviations of Children in the Three Experimental Groups

\begin{tabular}{|c|c|c|c|}
\hline & $\begin{array}{l}\text { Supportive } \\
\text { Mothers }\end{array}$ & $\begin{array}{l}\text { Non-supportive } \\
\text { Mothers }\end{array}$ & Control \\
\hline Mean age (yrs.) & 14.00 & 14.93 & 15.07 \\
\hline Standard Deviation & 2.16 & 2.05 & 1.97 \\
\hline $\mathrm{N}$ & 13 & 14 & 13 \\
\hline
\end{tabular}




\section{Table II}

Position in Family of Children

in the Three Experimental Groups

\begin{tabular}{lccc} 
Position & $\begin{array}{c}\text { Supportive } \\
\text { Mothers }\end{array}$ & $\begin{array}{c}\text { Non-supportive } \\
\text { Mothers }\end{array}$ & Control \\
\hline Only child & 3 & 3 & 2 \\
First & 6 & 7 & 5 \\
Second & 3 & 2 & 4 \\
Third & 1 & 2 & 1 \\
Fourth & & & 1
\end{tabular}

Table III

Composition of Families of Children

in the Three Experimental Groups

\begin{tabular}{lccc}
$\begin{array}{l}\text { Number of } \\
\text { Children }\end{array}$ & $\begin{array}{c}\text { Supportive } \\
\text { Mothers }\end{array}$ & $\begin{array}{c}\text { Non-supportive } \\
\text { Mothers }\end{array}$ & Control \\
\hline Only child & 3 & 3 & 2 \\
Two & 7 & 7 & 4 \\
Three & 1 & 3 & 4 \\
Four & 2 & 1 & 1 \\
Five & & 1 & 1 \\
Seven & & & 1
\end{tabular}

Table IV

Yearly Family Income Approximated from

Median Income Levels for Census TractsMeans and Standard Deviations

\begin{tabular}{lccc} 
& $\begin{array}{c}\text { Supportive } \\
\text { Mothers }\end{array}$ & Non-supportive & \\
& Mothers & Control \\
\hline Mean income & $\$ 24,138$ & $\$ 20,281$ & $\$ 22,191$ \\
Standard Deviation & $\$ 4,425$ & $\$ 3,038$ & $\$ 3,356$ \\
$\mathrm{~N}$ & 13 & 13 & 13
\end{tabular}




\section{Table V}

Physical and Emotional Abuse

of Children in the Three Experimental Groups

\begin{tabular}{lccr}
$\begin{array}{l}\text { Type of } \\
\text { Abuse }\end{array}$ & $\begin{array}{c}\text { Supportive } \\
\text { Mothers }\end{array}$ & $\begin{array}{c}\text { Non-supportive } \\
\text { Mothers }\end{array}$ & Contro \\
\hline $\begin{array}{l}\text { Physical by } \\
\text { father figure } \\
\begin{array}{l}\text { Physical by } \\
\text { mother }\end{array}\end{array}$ & 6 & 7 & 4 \\
$\begin{array}{l}\text { Emotional by } \\
\text { father figure }\end{array}$ & 3 & 6 & 5 \\
$\begin{array}{l}\text { Emotional by } \\
\text { mother }\end{array}$ & 9 & 10 & 9 \\
$N$ & 7 & 10 & 8 \\
& 13 & 14 & 13
\end{tabular}

Incest victims were compared on type of abuse that occurred and length of time since the sexual abuse came to light. This information is presented in Tables VI and VII.

Table VI

Type of Sexual Abuse of Incest Victims

\begin{tabular}{lcc}
$\begin{array}{l}\text { Type of } \\
\text { Abuse }\end{array}$ & $\begin{array}{c}\text { Supportive } \\
\text { Mothers }\end{array}$ & $\begin{array}{c}\text { Non-supportive } \\
\text { Mothers }\end{array}$ \\
\hline Rape & 2 & 6 \\
Sodomy & 2 & 2 \\
Sex Abuse & 9 & 6
\end{tabular}


Table VII

Year Sexual Abuse Uncovered

\begin{tabular}{lcc} 
Year & $\begin{array}{c}\text { Supportive } \\
\text { Mothers }\end{array}$ & $\begin{array}{c}\text { Non-supportive } \\
\text { Mothers }\end{array}$ \\
\hline 1978 & & 1 \\
1980 & & 2 \\
1982 & 2 & 1 \\
1983 & & 2 \\
1984 & 5 & 4 \\
1985 & 6 & 4
\end{tabular}

Three sets of scores on the Family Concept Inventory were compared across the three groups of subjects. These scores were:

(1) Family Effectiveness for the family as it is now, or the real

family; (2) Family Effectiveness for the ideal family; (3) Family

Satisfaction, the comparison of the two Family Effectiveness scores.

The complete list of scores on each of these three measures, for all

three groups, appears in Appendix A.

The means and standard deviations for the "Real" Family

Effectiveness scores are listed in Table VIII.

Table VIII

Real Family Effectiveness Scores-

Means and Standard Deviations

\begin{tabular}{lccc} 
& $\begin{array}{c}\text { Supportive } \\
\text { Mothers }\end{array}$ & $\begin{array}{c}\text { Non-supportive } \\
\text { Mothers }\end{array}$ & Control \\
\hline Mean & 23.38 & 13.28 & 20.80 \\
Standard Deviation & 14.03 & 7.78 & 11.34 \\
N & 13 & 14 & 13
\end{tabular}


These scores were compared by using the Kruskal-Wallis Analysis of Variance by Ranks. There was not a statistically significant difference across the groups, $\underline{H}(2)=5.08, \underline{p}<.10$. However, when the scores of incest victims with supportive mothers were compared to the scores of victims with non-supportive mothers by using the Mann-whitney $\underline{U}-$ Test, the result was a statistically significant difference, $\underline{U}=48.5, \underline{p}<.025$. The scores of incest victims with non-supportive mothers were also compared to the scores of the control group by using the Nann-Whitney U-Test. The result was a statistically significant difference, $\underline{U}=55.5, \underline{p}<.05$. Incest victims with non-supportive mothers ratea their families as less effective than did incest victims with supportive mothers and non-incest victims.

The means and standard deviations for the "Ideal" Family Effectiveness scores are listed in Table IX. (Two Ideal Family Effectiveness scores were deleted from the statistical analysis as they were considered invalid. This determination is made when the Real Family Effectiveness score for a subject is greater than the ideal score and/or the Ideal Family Effectiveness score is less than 25.) 
Table IX

\section{Ideal Family Effectiveness Scores- Means and Standard Deviations}

\begin{tabular}{lccc} 
& $\begin{array}{c}\text { Supportive } \\
\text { Mothers }\end{array}$ & $\begin{array}{c}\text { Non-supportive } \\
\text { Mothers }\end{array}$ & Control \\
\hline Mean & 42.41 & 38.38 & 41.92 \\
Standard Deviation & 4.35 & 9.09 & 5.6 \\
N & 12 & 13 & 13
\end{tabular}

When these scores were compared using the Kruskal-Wallis Analysis of Variance by Ranks, there was no statistically significant difference across the groups, $\underline{H}(2)=1.16, \underline{p}<.6$. All subjects rated their ideal families quite similarly.

The means and standard deviations for the Family Satisfaction scores are listed in Table $X$. (Two Family Satisfaction scores were deleted from the statistical analysis because the Ideal Family Effectiveness scores, which are used in the computation of the Family Satisfaction scores, were considered invalid.)

Table $\mathrm{X}$

Family Satisfaction ScoresMeans and Standard Deviations

\begin{tabular}{lccc} 
& $\begin{array}{c}\text { Supportive } \\
\text { Mothers }\end{array}$ & $\begin{array}{c}\text { Non-supportive } \\
\text { Mothers }\end{array}$ & Control \\
\hline Mean & .114 & -.22 & .131 \\
Standard Deviation & .66 & .47 & .775 \\
N & 12 & 13 & 13
\end{tabular}


When these scores were compared using the Kruskal-Wallis Analysis of Variance by Ranks, there was no statistically significant difference across the groups, $\underline{H},(2)=2.54, \underline{p}<.3$. The Family Satisfaction scores of incest victims with supportive mothers were compared to the scores of incest victims with non-supportive mothers using the Mann-Whitney $\underline{U}$-Test. There was no statistically significant difference between these scores: $\underline{U}=52$. (In order to reach the significance level of .05 , the $\underline{U}$ value would need to be at least as small as 47.) Incest victims with non-supportive mothers clearly rate their families as less effective than do incest victims with supportive mothers, but their feelings of dissatisfaction with their families are less clear. When the Family Satisfaction scores of incest victims with non-supportive mothers were compared to the Family Satisfaction scores of the control group by using the MannWhitney $\underline{U}$-Test, the result was not clearly significant. In this instance $\underline{U}=52$ and the critical value of $\underline{U}$ is 51 for $\underline{p}<.05$. 


\section{Chapter IV}

\section{Discussion}

The results of this study uphold the commonly held belief that the trauma of incest is less devastating to victims if their mothers are supportive of them. Incest victims with supportive mothers view their families as more effective and somewhat more satisfying than do incest victims with non-supportive mothers. Having a mother who believes that the sexual abuse has occurred and is instrumental in making the offender leave the home, appears to have a positive effect on the perception of the family by the incest victims.

It is not surprising to individuals who work with incest victims that mother's support is an important variable, but what is interesting is that incest victims with supportive mothers view their families as positively as do non-incest victims. It is true that the girls who made up the control group are involved with Children's Services Division because of family difficulties revolving around them. These families are in distress and undoubtedly family members would not view their families as approaching an ideal. (The scores for all three groups of subjects were lower than the normative scores for children in non-clinic, control families (van der Veen \& Olson, 1983).) I hoped that this factor would make this group more comparable to the experimental groups. Any differences 
in the way subjects rated their families would then appear to be truly due to incest and mother's support or lack of it, not to family problems in general.

The differences between the two groups of incest victims are obscured by the control group because its scores fall between the scores of the two experimental groups. Girls who are not thought to be incest victims actually think less of their families than do some incest victims. This is an important finding and supports the belief that a supportive mother is vital to the well being of an incest victim. Certainly the sexual abuse has had an impact on these victims but having supportive mothers has apparently decreased some of the distress they feel and positively affected the feelings the victims have about their families.

Perhaps it is, in fact, the actions of the mothers who have been defined as supportive that lead their daughters to view the families as effective. Being believed about something as difficult to divulge as incest is very powerful and enabling, especially when one is a child and the other party, the offender, is an adult and more likely to be believea. In addition to believing, if a child's mother, despite her own difficulties with the decision, makes the offender leave the home, she is showing a great deal of strensth. The child will unooubtedly be relieved since the sexual abuse will cease and the mother will be credited with playing a major role in this. A child in this situation may feel that her family is effective because of her mother's actions and attitudesbecause her mother believes her and acts to protect her. 
vost of the families with supportive mothers are involved in counseling and support groups for incest families. Incest victims with non-supportive mothers are also involved in these supportive experiences, but not with family members. This might also affect how a victim feels about her family, but this situation is one of the by-products of having a supportive mother. Supportive mothers attempt to do everything they can for their families so that everyone can recover from the effects of the incest. Of course this will probably have an effect on how family members view the family, but then that is one of the reasons why it is thought to be so important for victims to have supportive mothers.

That there was not a statistically significant difference between incest victims with supportive mothers and incest victims with non-supportive mothers on Family Satisfaction scores is in keeping with descriptions of typical incest families. Despite the trauma of being sexually ablised, a victim needs her family as she feels there is nowhere else for her needs to be met. Although she may realize that her family is ineffective in many ways, an incest victim has ambivalent feelings about her family and these feelings may be what were being expressed in the Family Satisfaction scores.

Incest victims with non-supportive mothers have often not lived with their families for some time. They may have come to imagine their families as being quite different than they truly are since it is too painful to deal with the reality of their 
situations. They often make various excuses for what has happenedespecially the positions their mothers have taken-and they defend their families. Since these behaviors are quite common, it is not difficult to see why some incest victims with non-supportive mothers would rate their families as satisfactory.

Some of the differences that were seen between incest victims with supportive mothers ard non-supportive mothers in demographic data might provide a partial explanation for support and lack of it. Many non-supportive mothers claim that they cannot leave their husbanajs or ask their husbands to leave home because the mothers cannot support themselves and their children financially. The fact that the income level of families with non-supportive mothers is significantly lower than that of families with supportive mothers lends some credibility to that argument (see p. 18 for $\underline{t}$ value). There is less money available to these families. Perhaps this is because the mothers do not work and they inight be hard pressed to make ends meet were their husbands to leave the home. The offenders might not make enough money to support two households.

The other factor that might explain in part why some mothers do not support their daughters when they expose incest is the type of abuse that occurred. Rape was more common among victims with non-supportive mothers than victims with supportive mothers. Perhaps acceptance of one's mate actually raping one's daughter is so much more difficult than acceptance of a lesser crime such as sex abuse that some mothers cannot bring themselves to do it. Some non- 
supportive mothers have actually admitted that if the sexual abuse had actually occurred they would have to kill their spouses.

The fact that the three groups of subjects did not differ in their Ideal Family Effectiveness scores is not at all surprising. Regardless of the trauma and turmoil a family is experiencing, the children in it basically know how a family is supposed to function and what they would like in an ideal family. They are not so confused by what has occurred in their families to lose the idea of an ideal.

The sample size for this study was quite small and therefore it may not be prudent to generalize from the results. However, since the results do support commonly held beliefs of professionals working with incest families, it seems that the results may, in fact, represent what occurs with these two groups of victims. Studying larger groups of incest victims would be useful to determine if the results of this study are valid, and if there are statistically significant differences in Family Satisfaction between incest victims with supportive and non-supportive mothers. 
REFERENCES

Adams-Tucker, C. (1982). Proximate effects of sexual abuse in childhood: A Report on 28 children. American Journal of Psychiatry, 139, 1252-1256.

Anderson, L. M., \& Shafer, G. (1979). The character-disordered family: A community treatment model for family sexual abuse. American Journal of Orthopsychiatry, 49, 436-445.

Berry, G. W. (1975). Incest: Some clinical variations on a classical theme. Journal of the American Academy of Psychoanalysis. 3. $151-1 \overline{61}$.

Borgman, R. (1984). Problems of sexually abused girls and their treatment. Social Casework, 64, 182-186.

Cavallin, H. (1966). Incestuous fathers: A clinical report. American Journal of Psychiatry, 122, 1132-1138.

de Young, M. (1982). Innocent seducer or innocently seduced? The role of the child incest victim. Journal of Clinical Child Psychology, 11, 56-60.

Gentry, C. E. (1978). Incestuous abuse of children: The need for an objective view. Child Welfare, 57, 355-364.

Gordon, L. \& O'Keefe, P. (1984). Incest as a form of family violence: Evidence from historical case records. Journal of Marriage and the family, $\underline{46}, 27-34$.

Herman, J. \& Hirschman, L. (1981). Families at risk for fatherdaughter incest. American Journal of Psychiatry, 138, 967-970.

Lustig, N., Dresser, J. W., Spellman, S. W., \& Murray, T. B. (1966). Incest: A family group survival pattern. Archives of General Psychiatry, 14, 31-40.

Molnar, G., \& Cameron, P. (1975). Incest syndromes: Observations in a general hospital psychiatric unit. Canadian Psychiatric Association Journal, 20, 373-377.

Rist, K. (1979). Incest: Theoretical and clinical views. American Journal of Orthopsychiatry, 49, 680-691. 
Russe11, D. (1984). Sexual Exploitation. Beverly Hills: Sage Publications.

Spencer, J. (1978). Father-daughter incest: A clinical view from the corrections field. Child Welfare, 57, 581-590.

Taubman, S. (1984). Incest in context. Social Work, 29, 35-40.

Taylor, R. (1984). Marital therapy in the treatment of incest. Social Casework, 65, 195-202.

Vander Mey, B. J. \& Neff, R. L. (1982). Adult-child incest: A review of research and treatment. Adolescence, 17, 717-735.

van der Veen, R. \& Olson, R. E. (1983). Manual and handbook for the Family Concept Assessment Method.

Zuelger, M. B., \& Reposa, R. E. (1983). Mothers in incestuous families. International Journal of Family Therapy, 5, 98-110. 
APPENDIX A 
Table XI

Ages of Subjects

\begin{tabular}{ccc}
$\begin{array}{c}\text { Supportive } \\
\text { Mothers }\end{array}$ & $\begin{array}{c}\text { Non-supportive } \\
\text { Mothers }\end{array}$ & Control \\
\hline 10 & 10 & 11 \\
10 & 12 & 14 \\
13 & 14 & 14 \\
13 & 14 & 14 \\
14 & 15 & 15 \\
14 & 15 & 16 \\
14 & 15 & 16 \\
15 & 15 & 16 \\
15 & 15 & 17 \\
15 & 16 & 17 \\
15 & 17 & 17 \\
17 & 17 & 17
\end{tabular}




$$
\begin{gathered}
\text { Table XII } \\
\text { Median Income Levels for Census Tracts } \\
\text { of Subjects' Residences }
\end{gathered}
$$

\begin{tabular}{lcc}
$\begin{array}{c}\text { Supportive } \\
\text { Mothers }\end{array}$ & $\begin{array}{c}\text { Non-supportive } \\
\text { Mothers }\end{array}$ & Control \\
\hline$\$ 12,477$ & $\$ 17,689$ & $\$ 17,373$ \\
$\$ 19,840$ & $\$ 17,689$ & $\$ 19,840$ \\
$\$ 21,351$ & $\$ 17,877$ & $\$ 19,840$ \\
$\$ 21,997$ & $\$ 17,877$ & $\$ 19,840$ \\
$\$ 23,358$ & $\$ 18,243$ & $\$ 20,068$ \\
$\$ 25,267$ & $\$ 19,118$ & $\$ 20,068$ \\
$\$ 25,267$ & $\$ 19,306$ & $\$ 21,300$ \\
$\$ 26,955$ & $\$ 19,896$ & $\$ 21,351$ \\
$\$ 26,955$ & $\$ 20,660$ & $\$ 23,198$ \\
$\$ 26,955$ & $\$ 21,997$ & $\$ 23,358$ \\
$\$ 26,955$ & $\$ 22,310$ & $\$ 26,955$ \\
$\$ 27,953$ & $\$ 22,528$ & $\$ 27,345$ \\
$\$ 28,463$ & $\$ 28,463$ & $\$ 953$
\end{tabular}


Table XIII

Real Family Effectiveness Scores

\begin{tabular}{ccc}
$\begin{array}{c}\text { Supportive } \\
\text { Mothers }\end{array}$ & $\begin{array}{c}\text { Non-supportive } \\
\text { Mothers }\end{array}$ & Control \\
\hline 6 & 5 & 7 \\
9 & 7 & 8 \\
9 & 8 & 12 \\
9 & 8 & 14 \\
15 & 8 & 17 \\
16 & 9 & 26 \\
22 & 11 & 27 \\
24 & 12 & 27 \\
31 & 12 & 27 \\
37 & 14 & 29 \\
38 & 21 & 36 \\
46 & 15 & 38 \\
& 21 & 26
\end{tabular}




\section{Table XIV}

\section{Ideal Family Effectiveness Scores}

\begin{tabular}{ccc}
$\begin{array}{c}\text { Supportive } \\
\text { Mothers }\end{array}$ & $\begin{array}{c}\text { Non-supportive } \\
\text { Mothers }\end{array}$ & Control \\
\hline 33 & 23 & 35 \\
39 & 26 & 39 \\
39 & 28 & 41 \\
39 & 40 & 42 \\
40 & 40 & 43 \\
44 & 43 & 43 \\
44 & 44 & 45 \\
45 & 46 & 45 \\
46 & 46 & 46 \\
47 & 46 & 46
\end{tabular}


Table XV

Family Satisfaction Scores

\begin{tabular}{|c|c|c|}
\hline $\begin{array}{l}\text { Supportive } \\
\text { Mothers }\end{array}$ & $\begin{array}{c}\text { Non-supportive } \\
\text { Mothers }\end{array}$ & Control \\
\hline-.657 & -.741 & -.661 \\
\hline-.582 & -.701 & -.617 \\
\hline-.49 & -.668 & -.576 \\
\hline-.438 & -.663 & -.483 \\
\hline-.352 & -.543 & -.231 \\
\hline .051 & -.369 & .222 \\
\hline .085 & -.332 & .231 \\
\hline .487 & -.131 & .259 \\
\hline .663 & -.101 & .285 \\
\hline .845 & .092 & .34 \\
\hline 1.287 & .121 & .541 \\
\hline 1.472 & .31 & .629 \\
\hline & .857 & 2.223 \\
\hline
\end{tabular}


APPENDIX B 
Dear

I am a caseworker at Children's Services Division. I am conducting a research study regarding children's feelings about their families. I will be administering a test called the Family concept Inventory in which test takers identify which of 80 items describing social-emotional aspects of family life apply to their family as it is now. Test takers then identify which of the 80 items apply to their ideal family. It is a simple test to take and should not have any adverse effects on someone taking it.

If you allow your daughter to participate in my study, either your caseworker or I will give her the test. I will also gather certain information such as age, urban or rurual residence, etc. that might affect the test results. There will be only one testing session. This session will take thirty to forty minutes.

Your daughter's test form will be numbered. Her name will not be recorded on the form. No one will know which girl filled out which test form, including myself.

Participation in my study is entirely voluntary for you and your daughter. Whatever you decided, your status with Children's Services Division will not change in any way.

I sincerely hope you will allow your daughter to participate in the study because we hope that this information will allow us to help more children. Since your child's responses will be anonymous, it is unlikely that there will be any direct benefit to her from taking the test. However, we hope that this information will help us in our efforts to help families solve their problems with their children. I have enclosed a permission form. Please fill it out and mail it back to me in the envelope I have also enclosed.

If you or your child experience problems that are the results of your child's participation in this study, please contact victor $C$. Dahl, Office of Graduate Studies and Research, 105 Neuberger Hall, Portland State University, 229-3423.

Thank you.

Sincerely,

Sharon Hitchens 
Parental Permission Form

I hereby give my permission for my child, to participate in a research study conducted by Sharon titchens regarding childrens' opinions about their families. I understand that my child's identity will remain anonymous through-out the study. The name of my child will not be recorded and her test form will be identified only by a number. No one will know which answers my child gave, not even the researcher or any parents. My child will be tested once for a thirty to forty minute period. I understand that my child's participation in this study is entirely voluntary. Whatever I decide, my status with Children's Services Division will not change in any way.

Signed: Date:

Parent or Guardian Witness: 
Subject Consent Form

I, - agree to participate in a research

Name of child

study conducted by Sharon Hitchens regarding children's opinions about their families. My name will not be recorded and my test form will be identified only by a number. No one will know what answers I gave, not even the researcher or my parents. I understand I will be tested once for a thirty to forty minute period and that is all that will be necessary. I also understand that my participation in this study is completely voluntary.

Signed:

Date:

Subject

Witness: 
Physical and Emotional Abuse Rating Sheet

Please place an $x$ on each of the following scales to denote the degree of abuse perpetrated, with 0 being no abuse and 10 being extreme abuse.

Child:

By mother, step-mother, or mother-figure

Physical abuse

$\begin{array}{lllllllllll}0 & 1 & 2 & 3 & 4 & 5 & 6 & 7 & 8 & 9 & 10\end{array}$

Emotional abuse

$\begin{array}{lllllllllll}0 & 1 & 2 & 3 & 4 & 5 & 6 & 7 & 8 & 9 & 10\end{array}$

By father, step-father, or father-figure

Physical abuse

$\begin{array}{lllllllllll}0 & 1 & 2 & 3 & 4 & 5 & 6 & 7 & 8 & 9 & 10\end{array}$

Emotional abuse

$\begin{array}{lllllllllll}0 & 1 & 2 & 3 & 4 & 5 & 6 & 7 & 8 & 9 & 10\end{array}$


APPENDIX C 
(real)

\section{FAMILY CONCEPT INVENTORY - $\mathrm{R}$}

\section{Instructions:}

For each of the items, circle the number that shows how true the item is for your family as it is now.

You can circle any number, from "O" to " 8 ". At one end, " 0 " means the item is completely false for your present family. At the other end, " 8 ". means it is very true for your family as it presently is.

Circle one number to the right of each item. Please make no other marks on the paper.

For example, if your family is now very active, you would score the sample item this way:

$$
\begin{gathered}
\text { Least like } \\
\text { present family }
\end{gathered}
$$

Most like present family

SAMPLE: We are an active family.

$$
\begin{array}{lllllllll}
0 & 1 & 2 & 3 & 4 & 5 & 6 & 7 & 8
\end{array}
$$

If your family was not at all active, you would have circled the "on. If it was neither active nor inactive, you would have circled the "4".

Use the various numbers in all of the positions, whichever best fits your answer, from "0", completely false, to "8", very true.

Please ask any questions if it is not clear what to do. Fill in your complete name at the bottom of this page, and go ahead and answer each item according to how well it fits your family as it actually is now. Answer every item and be as careful and as accurate as you can.

Thank you.

Name

Date

(C) Ferdinand van der Veen, Ph.D., 1969. 


\section{Family Unit Inventory}

1. We like to do new and different things.

2. We can usually depend on each other.

3. We have number of close friends.

4. We often do not agree on important matters.

5. Each of us tries to be the kind of person the others will like.

6. Good manners and proper behavior are very importent to us.

7. We feel secure (safe) when we are with each other.

8. We want help with our problems.

9. We do many things together.

10. Each of us wants to tell the others what to do.

11. There are serious differences in our beliefs about what is right and important.

12. We feel free to express any thought or feel- $0 \begin{array}{lllllllll}0 & 2 & 3 & 4 & 5 & 6 & 7 & 8\end{array}$ ing to each other.

13. Our home is the center of our activities.

14. We are an affectionate family (show our love for each other).

15. The difficulties that we have in the family are not our fault.

\begin{tabular}{|c|c|c|c|c|c|c|c|c|c|}
\hline \multirow{2}{*}{\multicolumn{2}{|c|}{$\begin{array}{l}\text { Least } \\
\text { like }\end{array}$}} & \multicolumn{3}{|c|}{ Present } & \multicolumn{3}{|c|}{ Family } & \multirow[b]{2}{*}{$\begin{array}{c}\text { Most } \\
\text { like }\end{array}$} & \multirow[b]{3}{*}{ (1) } \\
\hline & & & & & & & & & \\
\hline 0 & 1 & 2 & 3 & 4 & 5 & 6 & 7 & 8 & \\
\hline 0 & 1 & 2 & 3 & 4 & 5 & 6 & 7 & 8 & (2) \\
\hline 0 & 1 & 2 & 3 & 4 & 5 & 6 & 7 & 8 & (3) \\
\hline 0 & 1 & 2 & 3 & 4 & 5 & 6 & 7 & 8 & (4) \\
\hline 0 & 1 & 2 & 3 & 4 & 5 & 6 & 7 & 8 & (5) \\
\hline 0 & 1 & 2 & 3 & 4 & 5 & 6 & 7 & 8 & $(6)$ \\
\hline 0 & 1 & 2 & 3 & 4 & 5 & 6 & 7 & 8 & (7) \\
\hline 0 & 1 & 2 & 3 & 4 & 5 & 6 & 7 & 8 & $(8)$ \\
\hline 0 & 1 & 2 & 3 & 4 & 5 & 6 & 7 & 8 & (9) \\
\hline 0 & 1 & 2 & 3 & 4 & 5 & 6 & 7 & 8 & (10) \\
\hline 0 & 1 & 2 & 3 & 4 & 5 & 6 & 7 & 8 & (11) \\
\hline 0 & 1 & 2 & 3 & 4 & 5 & 6 & 7 & 8 & (12) \\
\hline 0 & 1 & 2 & 3 & 4 & 5 & 6 & 7 & 8 & (13) \\
\hline 0 & 1 & 2 & 3 & 4 & 5 & 6 & 7 & 8 & (14) \\
\hline 0 & 1 & 2 & 3 & 4 & 5 & 6 & 7 & 8 & (15) \\
\hline & $\begin{array}{l}\text { ast } \\
\text { ke }\end{array}$ & & & & & & & $\begin{array}{l}\text { Most } \\
\text { like }\end{array}$ & \\
\hline & & & res & ent & & $\mathrm{m} 11$ & & & \\
\hline
\end{tabular}

(Continue to next page)

(C) Ferdinand van der Veen, Ph.D., 1969. 
Present Family

\begin{tabular}{|c|c|c|c|c|c|c|c|c|}
\hline \multicolumn{2}{|c|}{$\begin{array}{l}\text { Least } \\
\text { like }\end{array}$} & \multirow[b]{2}{*}{2} & \multirow[b]{2}{*}{3} & \multirow[b]{2}{*}{4} & \multirow[b]{2}{*}{5} & \multirow[b]{2}{*}{6} & \multirow[b]{2}{*}{7} & \multirow{2}{*}{$\begin{array}{l}\text { Most } \\
11 \mathrm{ke} \\
8\end{array}$} \\
\hline 0 & 1 & & & & & & & \\
\hline 0 & 1 & 2 & 3 & 4 & 5 & 6 & 7 & 8 \\
\hline 0 & 1 & 2 & 3 & 4 & 5 & 6 & 7 & 8 \\
\hline 0 & 1 & 2 & 3 & 4 & 5 & 6 & 7 & 8 \\
\hline 0 & 1 & 2 & 3 & 4 & 5 & 6 & 7 & 8 \\
\hline 0 & 1 & 2 & 3 & 4 & 5 & 6 & 7 & 8 \\
\hline 0 & 1 & 2 & 3 & 4 & 5 & 6 & 7 & 8 \\
\hline 0 & 1 & 2 & 3 & 4 & 5 & 6 & 7 & 8 \\
\hline 0 & 1 & 2 & 3 & 4 & 5 & 6 & 7 & 8 \\
\hline 0 & 1 & 2 & 3 & 4 & 5 & 6 & 7 & 8 \\
\hline 0 & 1 & 2 & 3 & 4 & 5 & 6 & 7 & 8 \\
\hline 0 & 1 & 2 & 3 & 4 & 5 & 6 & 7 & 8 \\
\hline 0 & 1 & 2 & 3 & 4 & 5 & 6 & 7 & 8 \\
\hline 0 & 1 & 2 & 3 & 4 & 5 & 6 & 7 & 8 \\
\hline 0 & 1 & 2 & 3 & 4 & 5 & 6 & 7 & 8 \\
\hline 0 & 1 & 2 & 3 & 4 & 5 & 6 & 7 & 8 \\
\hline 0 & 1 & 2 & 3 & 4 & 5 & 6 & 7 & 8 \\
\hline & & & & & & & & $\begin{array}{l}\text { Most } \\
11 \mathrm{ke}\end{array}$ \\
\hline & & & es & & & $1 i 1 y$ & & \\
\hline
\end{tabular}

17. We do not understand each other.

18. We get along very well in the community.

19. We often praise or compliment each other.

20. We avold talking about sexual matters.

21. We get along much better with persons outside the family than with each other.

22. If we had more money most of our present problems would be gone.

23. We are proud of our family.

24. We do not like each other's friends.

25. There are many conflicts (disagreements) in our family.

26. We are usually calm and relaxed when we are together.

27. We are not a talkative family.

28. We respect each other's privacy.

29. Accomplishing (actually getting done) what we want to do seems to be difficult for us.

30. We tend to worry about many things. 31. We often upset each other without meaning
to. us.

\section{Present Family}


33. We are religious family.

34. We are continually getting to know each other better.

35. We need each other.

36. We do not spend enough time together.

37. We do not understand what is causing our difficulties.

38. Success and reputation are very important to us.

39. We encourage each other to develop in his or her own individual way.

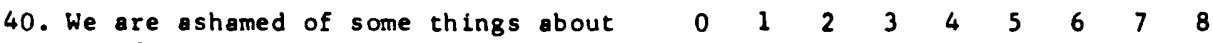
our family.

R3

Present Family

Most

like

$\begin{array}{lllllllll}0 & 1 & 2 & 3 & 4 & 5 & 6 & 7 & 8\end{array}$


Present Family

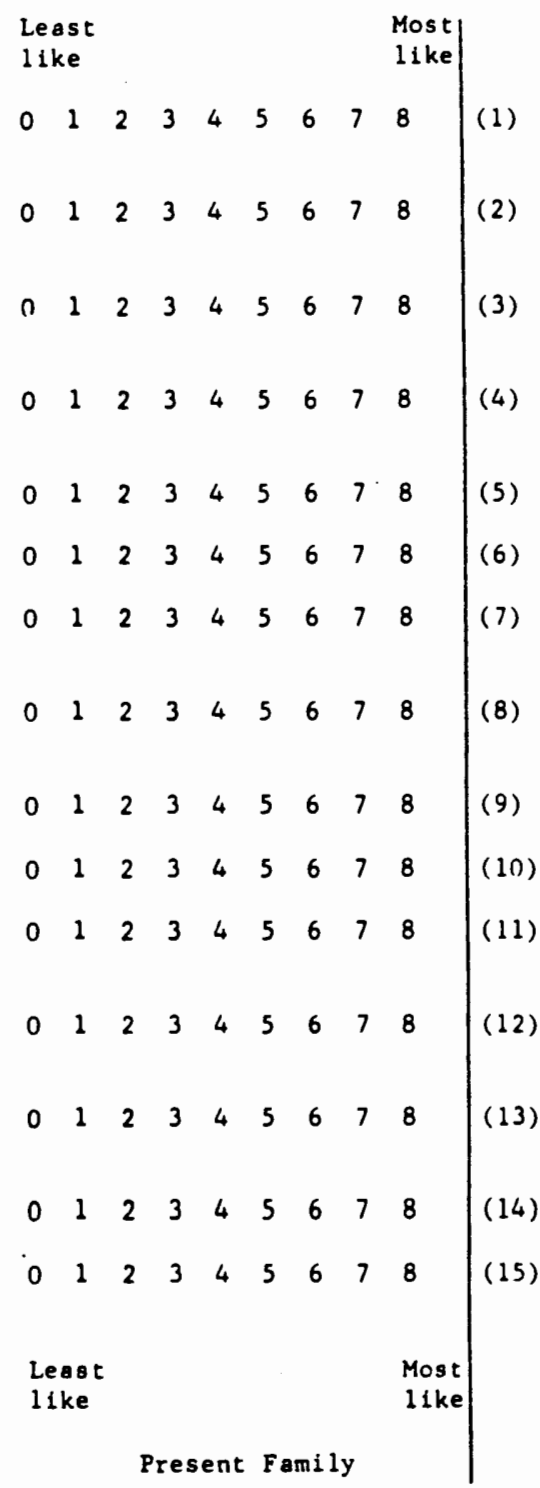


Present Fomily

56. We often become angry at eoch other.

57. We live largely by other people's standards and values (what is right and important.)

58. We are not as happy together as we might be.

59. We are critical of each other.

60. We are satisfied with the way in which we now live.

61. Usually each of us goes his own separate way.

62. We resent each other's outside activities.

63. We have respect for each other's feelings and opinions even when we differ strongly.

64. We sometimes wish we could be on entirely different family.

65. We are sociable and really enfoy being with people.

66. We are disorganized (mixed up) family.

67. It is important to us to know how we appear to others.

68. Our decisions are not our own, but forced upon us by things beyond our control.

69. We have little fondness for each other.

70. We are atrong, competent (able) family.

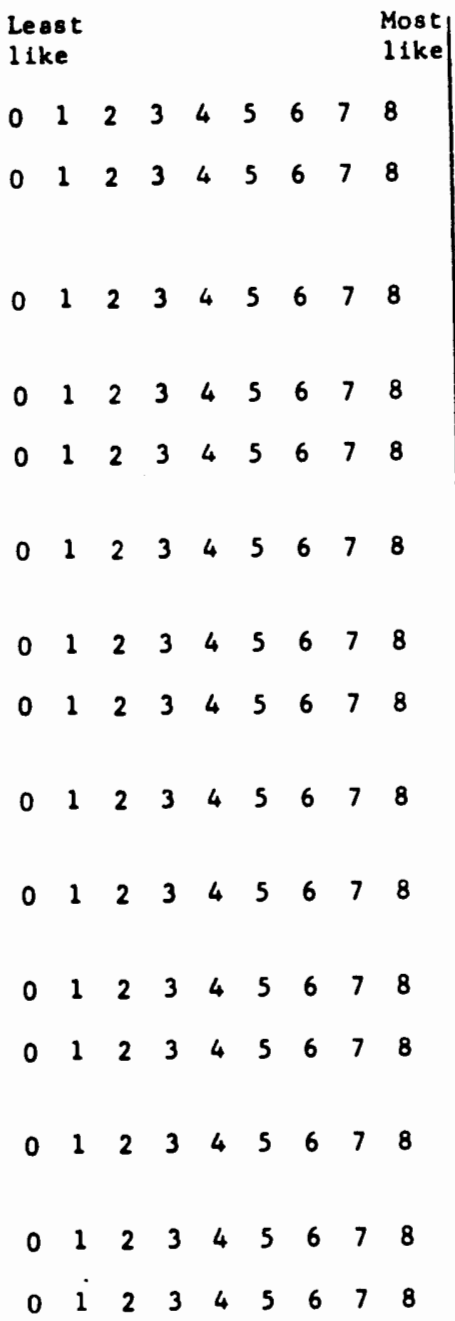


Present Family

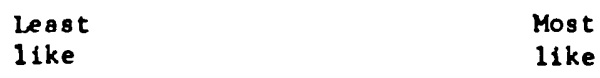

71. We avoid telling each other our real $0 \quad 1 \quad 2 \quad 3 \quad 4 \quad 5 \quad 6 \quad 7 \quad 8$ feelings.

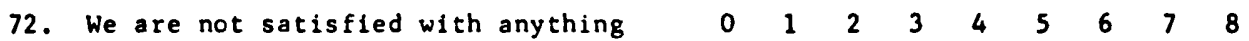
short of perfection.

73. We forgive each other easily.

74. We are usually somewhat reserved with each other

75. We hardly ever hurt each other's feelings.

76. We like the same things.

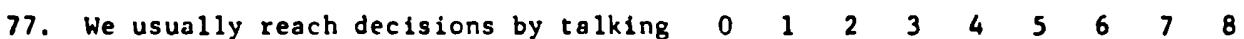
it over and some give and take.

78. We can adjust well to new situations. $0 \quad 1 \quad \begin{array}{llllllll} & 0 & 3 & 4 & 5 & 6 & 7 & 8\end{array}$

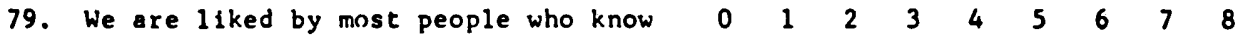
us .

80. We are full of 1 ife and good spirits. Please Fill In:

Sex Birth Date

Occupation of father (please describe)

Education of father (years \& highest degree)

Occupation of mother

Education of mother

$\begin{array}{lllllllll}0 & 1 & 2 & 3 & 4 & 5 & 6 & 7 & 8\end{array}$

Number of childien in family

Ycur rank in your family of origin (oldest child, youngcst, middle)

Race.

Religion

(Do not write in this space)

Card number

Test form

Occupation of father

Education of father

No. of children

Rank of rater

Age of rater

Sex of rater

Test stage

Test date

Missing dato

lest code

Group code

MC $1(68-70)$

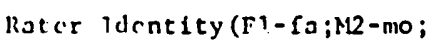

$$
\text { C3-chi) }
$$

Fonily ID code

Thonk you. 
(ideal)

\section{FAMILY CONCEPT INVENTORY - I}

\section{Instructions:}

For each of the items, circle the number that shows how true the item is for your family as you would ideally like it to be. It does not matter what your family is actually like, only what you most want it to be like.

You can circle any number from " 0 " to " 8 ". At one end, " 0 " means the item is completely false for your ideal family. At the other end, " 8 " means it is very true for your ideal family.

Circle one number to the right of each item. Please make no other marks on the paper.

Por example, if you would want your family to ideally be somewhat active, you would mark the sample ite!n in this way:

$$
\begin{aligned}
& \text { Least like } \\
& \text { ideal family }
\end{aligned}
$$

Most like ideal family

SAMPLE: We are an active family. 0 1 2 ( 345 (6) 78

If you would strongly like your ideal family to be very active, you would have circled the " $g^{n}$. If you did not want it to be ejther active or inactive, you would have circled the " 4 ". If you did not want it to be active at all, you would have circled the "O".

Use the various numbers in all of the positions, whichever best fits your answer, from " 0 ", completely false, to "8", very true.

Please ask any questions if $1 \mathrm{t}$ is not clear what to do. Fill in your complete name at the bottom of this page, and go ahead and answer each item according to how well it fits your family as you would most like it to be. Be as careful and accurate as you can and answer all the items.

Thank you.

Name:

Date:

(C) Ferdinand van der Veen. Ph.D., 1969. 


\section{Eam11\% Un1t Inventory}

Ideal Family
like

1. We like to do new and different things.

$\begin{array}{lllllllll}0 & 1 & 2 & 3 & 4 & 5 & 6 & 7 & 8 \\ 0 & 1 & 2 & 3 & 4 & 5 & 6 & 7 & 8 \\ 0 & 1 & 2 & 3 & 4 & 5 & 6 & 7 & 8\end{array}$

3. We bave a number of close frlends.

4. We often do not agree on important matters. $\begin{array}{llllllllll}0 & 1 & 2 & 3 & 4 & 5 & 6 & 7 & 8\end{array}$

5. Each of us tries to be the kind of person tive others will like.

6. Good manners and proper behavior ure very important to us.

$$
\begin{array}{lllllllll}
0 & 1 & 2 & 3 & 4 & 5 & 6 & 7 & 8 \\
0 & 1 & 2 & 3 & 4 & 5 & 6 & 7 & 8
\end{array}
$$

7. We feel secure (anfe) when we are with each otirer.

8. We want help with our problems.

9. We do many things together.

10. Each of us wants to tell the others what $\begin{array}{llllllllll}0 & 1 & 2 & 3 & 4 & 5 & 6 & 7 & 8\end{array}$ to do.

11. There are serlous differences in sur beliefs about what is right and important. $0 \quad 1 \quad 2 \quad 3 \quad 4 \quad 5 \quad 6 \quad 7 \quad 8$

12. We feel free to expiess any thougit or $\begin{array}{llllllllllll}\text { feeling to each other. } & 0 & 1 & 2 & 3 & 4 & 5 & 6 & 7 & 8\end{array}$

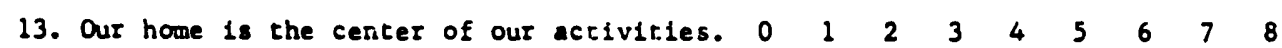

14. We are an affectionate famlly (show our $\quad 0 \quad 1 \quad 2 \quad 3 \quad 4 \quad 5 \quad 6 \quad 7 \quad 8$ love for each other).

15. The difficulties that we have in the $\quad 0 \quad 1 \quad 7 \quad 3 \quad 4 \quad 5 \quad 6 \quad 7 \quad 8$ famlly are not our fault. 
Ideal Famlly

$\begin{array}{llllllllll}\begin{array}{l}\text { Least } \\ \text { like }\end{array} & & & & & & \begin{array}{r}\text { Most } \\ \text { I1ke }\end{array} \\ 0 & 1 & 2 & 3 & 4 & 5 & 6 & 7 & 8 \\ 0 & 1 & 2 & 3 & 4 & 5 & 6 & 7 & 8 \\ 0 & 1 & 2 & 3 & 4 & 5 & 6 & 7 & 8 \\ 0 & 1 & 2 & 3 & 4 & 5 & 6 & 7 & 8\end{array}$
for us.

17. We do not understand each other.

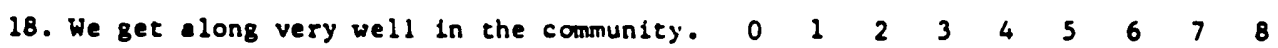

19. We often praise or compliment each other. $0 \quad 1 \quad 2 \quad 3 \quad 4 \quad 5 \quad 6 \quad 7 \quad 8$

20. We evold talking about sexual matters. $\quad 0 \quad 1 \quad 2 \quad 3 \quad 4 \quad 5 \quad 6 \quad 7 \quad 8$

21. We get long much better with persons $\quad 0 \quad 1 \quad 2 \quad 3 \quad 4 \quad 5 \quad 6 \quad 7 \quad 8$ outside the family than with each other.

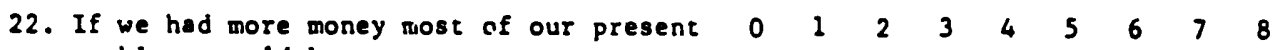
problems would be gone.

23. We are proud of our farily.

24. We do not like each other's friends.

$\begin{array}{lllllllll}0 & 1 & 2 & 3 & 4 & 5 & 6 & 7 & 8\end{array}$

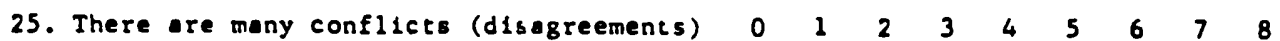
in our family.

26. We are usually calm and relaxed when we 0 l $2 \begin{array}{lllllllll} & 3 & 4 & 5 & 6 & 7 & 8\end{array}$ are together.

27. We are not talkative family.

28. We respect each other's privacy.

29. Accomplishing (actually getting done) what we want to do seems to be difficult for us.

30. We tend to worry about many things.

31. We often upset each other without meaning to.

$\begin{array}{lllllllll}0 & 1 & 2 & 3 & 4 & 5 & 6 & 7 & 8\end{array}$

(27)

$\begin{array}{lllllllll}0 & 1 & 2 & 3 & 4 & 5 & 6 & 7 & 8\end{array}$

$\begin{array}{lllllllll}0 & 1 & 2 & 3 & 4 & 5 & 6 & 7 & 8\end{array}$

32. Nothing exciting ever seems to happen to us.

33. We are a religious family.

34. We are continually getting to know each better.

35. We need each other.

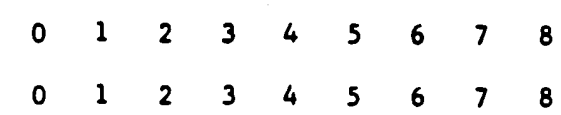

$\begin{array}{lllllllll}0 & 1 & 2 & 3 & 4 & 5 & 6 & 7 & 8\end{array}$

$\begin{array}{lllllllll}0 & 1 & 2 & 3 & 4 & 5 & 6 & 7 & 8\end{array}$

)


I3

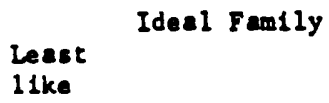

11ke

like

36. We do not spend enough time together.

$$
\begin{array}{lllllllll}
0 & 1 & 2 & 3 & 4 & 5 & 6 & 7 & 8
\end{array}
$$

37. We do not understand what is causing

$\begin{array}{lllllllll}0 & 1 & 2 & 3 & 4 & 5 & 6 & 7 & 8\end{array}$
our difficulties.

38. Success and reputation are very important $0 \quad 1 \quad 2 \quad 3 \quad 4 \quad 5 \quad 6 \quad 7 \quad 8$ to 48.

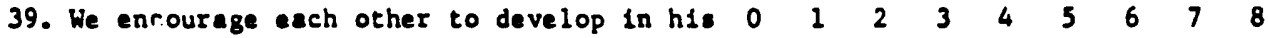
or her own individual way.

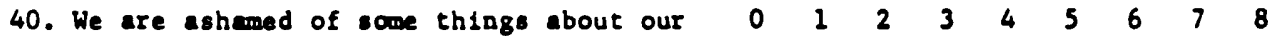
$(40)$ fanily.

(Do not write in this opace)
Card number
Test form
Occupation of father
Education of father
No. of children
Rank of rater
Age of rater
Sex of rater
Test stage
Test date
Missing data
Test code
Group code
Rater Ident1ty
Fanily Il couse
Deck number


41. We have warm, close reiationshlps with $0 \quad 1 \quad 2 \quad 3 \quad 4 \quad 5 \quad 6 \quad 7$. each other.

42. There are some thinge which ve avold talking about.

$\begin{array}{lllllllll}0 & 1 & 2 & 3 & 4 & 5 & 6 & 7 & 8\end{array}$

43. Together we can overcome almost any

$\begin{array}{lllllllll}0 & 1 & 2 & 3 & 4 & 5 & 6 & 7 & 8\end{array}$ difficuley.

44. We really do truet and confide in each other.

45. We make many demands on each other.

46. We take care of each other.

47. Our actsvitles together are usually planned and organtzed.

$\begin{array}{lllllllll}0 & 1 & 2 & 3 & 4 & 5 & 6 & 7 & 8\end{array}$

48. The farily has always been very Important $0 \quad 1 \quad 2 \quad 3 \quad 4 \quad 5 \quad 6 \quad 78$ to us.

$\begin{array}{lllllllll}0 & 1 & 2 & 3 & 4 & 5 & 6 & 7 & 8\end{array}$

$\begin{array}{lllllllll}0 & 1 & 2 & 3 & 4 & 5 & 6 & 7 & 8\end{array}$

$\begin{array}{lllllllll}0 & 1 & 2 & 3 & 4 & 5 & 6 & 7 & 8\end{array}$

49. It is hard for us to please each other.

$\begin{array}{lllllllll}0 & 1 & 2 & 3 & 4 & 5 & 6 & 7 & 8\end{array}$

50. We are considerate of each other.

51. We can stand up for our righte if $\begin{array}{lllllllll}0 & 1 & 2 & 3 & 4 & 5 & 6 & 7 & 8\end{array}$ necessary.

$\begin{array}{lllllllll}0 & 1 & 2 & 3 & 4 & 5 & 6 & 7 & 8\end{array}$

52. We are all reoponolble for fanily problems.

$\begin{array}{lllllllll}0 & 1 & 2 & 3 & 4 & 5 & 6 & 7 & 8\end{array}$

53. There 1s not enough diec1pline in our fandly.

$\begin{array}{lllllllll}0 & 1 & 2 & 3 & 4 & 5 & 6 & 7 & 8\end{array}$

54. We have very good trine together.

$\begin{array}{lllllllll}0 & 1 & 2 & 3 & 4 & 5 & 6 & 7 & 8\end{array}$

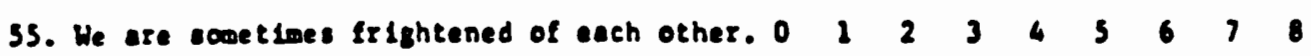

Leset

Host

llke

Ideal Fandly

(Continue so aext page) 
56. We often become engry at each otiner. $\quad \begin{array}{llllllllll} & 0 & 1 & 2 & 3 & 4 & 5 & 6 & 7 & 8\end{array}$ (16)

57. We live largely by other people's standards and values (wnat is right and Important).

58. We a:e not as happy togetier as we $\quad \begin{array}{llllllllll}8 & 0 & 1 & 2 & 3 & 4 & 5 & 6 & 7 & 8\end{array}$ might be.

59. We are critical of each other.

60. We are satisfled with the way in which $0 \quad 1 \quad 2 \quad 3 \quad 4 \quad 5 \quad 6 \quad 7 \quad 8$ we now live.

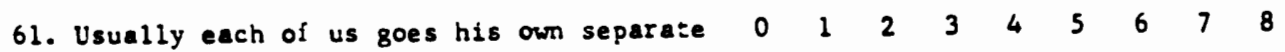
way.

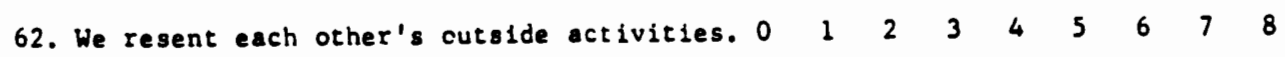

63. We have respect for each other'e feellags and opintons even when we differ strongly. $0 \begin{array}{lllllllll} & 2 & 3 & 4 & 5 & 6 & 7 & 8\end{array}$

64. We sometimes wish we could be an entizely $0 \quad 1 \quad 2 \quad 3 \quad 4 \quad 5 \quad 6 \quad 7 \quad 8$ different family.

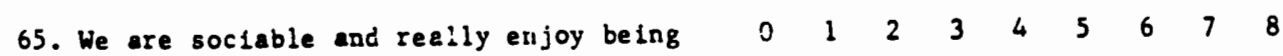
with people.

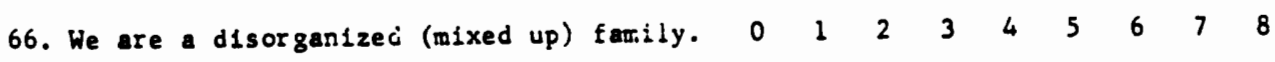

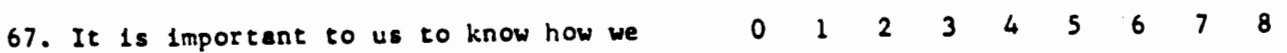
appear to others.

58. Our decisions are not our own, but aze forced upon us by things beyond our control.

69. We have little foidness ior each other. $\begin{array}{llllllllll} & 0 & 1 & 2 & 3 & 4 & 5 & 6 & 7 & 8\end{array}$

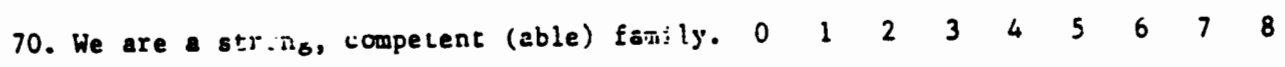

(Continue to next page) 
Ideal Fanily

$\begin{array}{ll}\text { Least } & \text { Most } \\ \text { like } & \text { like }\end{array}$

71. We ovold telling each other our real $0 \quad 1 \quad 2 \quad 3 \quad 4 \quad 5 \quad 6 \quad 7$ 8 feelings.

72. We are not satisfied with anything short of perfection.

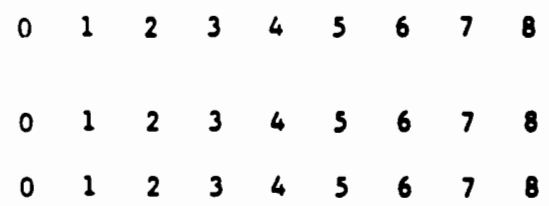

